\title{
Germans debate maglev train
} Go-ahead for

THE future of West Germany's plans to build a magnetically levitated train called 'Transrapid' is looking increasingly uncertain. Transport Minister Friedrich Zimmermann said recently that his ministry would not spend "a single deutsche mark" on Transrapid. Zimmermann fears that the system would compete with the staterun conventional railway system, from which the government recently assumed DM12,600 million of debt.

The Research Ministry has already invested DM1,200 million (about $\$ 615$ million) in the project, but it has now withdrawn its support. A further DM3,000 million in long-term loans is needed to finance the next phase.

Initial plans were for a route connecting Hamburg and Hanover, reducing the train travel time for the 155-kilometre distance from 80 minutes to just $30-40$ minutes. But a second stretch in the Ruhr area linking Essen and Bonn is now being considered. The West German cabinet is expected to debate the matter in October.

The consortium to build Transrapid is led by Thyssen Henschel and includes Messerschmitt-Bölkow-Blohm and several of the largest banks in West Germany. The consortium has itself invested about DM100 million in the project so far.

Thyssen admits that Transrapid can be profitable in West Germany only if two distant cities are connected. It has recently raised the stakes by offering to build a $1,025-\mathrm{km}$ track between Hamburg in the north and Munich in the south, looping

\section{Munich}

past the Ruhr and Rhine valleys on the way. Such a track could cost between DM30,000 million and DM45,000 million. It would take at least 15 years to complete, not counting the time spent fighting court battles against environmentalist opponents of the project.

Although in the 1960 s maglev trains were thought of as the best way to link major European cities, the technology has been turned down by the French, the British and others in favour of improving conventional railways. Even West Germany has invested heavily in improving its high-speed intercity rail network with trains that can travel up to 250 kilometres an hour.

Thyssen conducted a publicity campaign this summer to try to win support for Transrapid. Spokesman Lutz Dreesbach said that Transrapid is meant to complement the conventional rail network, not to compete. The plan to link Hamburg and Munich would also link seven major airports, providing significant relief for the overcrowded air lanes in West Germany, he said. Dreesbach argues that Japanese plans to build a maglev system should motivate West Germany to back its own superior technology.

The West Germans claim to be three or four years ahead of Japan, which they see as the main competitor in the potentially lucrative US market. Transrapid, which uses conventional magnets, last year set a speed record for a levitating train (with passengers) of 412 kilometres an hour.

Steven Dickman

\section{Australia plans high-speed train link}

\section{Sydney}

Australia's plans for a Very Fast Train (VFT) link between Sydney and Melbourne have won the endorsement of Prime Minister Bob Hawke. In order to speed up the project, a Senate standing committee is to be established to examine the environmental, employment and development implications of VFT.

The train, described by Hawke as "the most important post-war development in Australia", will will travel at top speeds of 350 kilometres an hour, providing the fastest commercial train service in the world. The line should be in service by 1996 at a cost of $\mathbf{A} \$ 4,500$ million. Finance will come from private companies, including Broken Hill Pty Ltd, TNT, Elders IXL and the Japanese construction group Kumagai Gumi.

VFT will be important not just as a transport system but as a means of developing the Sydney-Melbourne corridor - a distance of about 1,000 kilometres, much of it relatively isolated. According to Alan Castleman, chief executive of the VFT Joint Venture, there will be several types of service. Twelve express trains a day will travel direct from Sydney to Melbourne in just over three hours. From city centre to city centre, the travel time will be the same as by taking an aeroplane. Twelve daily trains will stop at 14 towns between the two major cities as well as providing an express service to Canberra. Journey times between Sydney and Canberra will be cut from four hours to one hour.

According to Castleman, VFT will be travelling at $\mathbf{3 5 0}$ kilometres an hour for most of its route. The French TGV Atlantic presently travels from Paris to Lyon at peak speeds of $\mathbf{3 0 0}$ kilometres an hour, and the TGV Nord planned for 1993 will travel at 320-330 kilometres an hour on the way to the Channel tunnel. Whether the VFT can maintain such speeds routinely over distances much greater than in France is being questioned.

\section{Tokyo}

JAPAN took a step towards developing a commercial railway line for a high-speed magnetically levitated (Maglev) train two weeks ago with a decision to locate a new 40-45 kilometre test track for the Maglev in Yamanashi Prefecture, about 100 kilometres west of Tokyo. The test track may later be extended to link Tokyo and Osaka for commercial operations. But before that many technological, economic and political hurdles have to be overcome.

The Yamanashi site was chosen by a Transport Ministry committee over two other possible sites, one in the northern island of Hokkaido, the other in the southern island of Kyushu where there is already a 7-km test track for the Maglev. The ministry will apply for $¥ 6,000$ million (\$45 million) in fiscal year 1990 towards the cost of developing the track when budget requests are submitted at the end of this month. Total cost of the test track, trains and related facilities will be about $¥ 350,000$ million and this is expected to be shared by the national government, the local Yamanashi government and one of the Japan Railway (JR) companies, JR Tokai, which was formed after the privatization of the Japan National Railways (JNR) in 1987.

The test line will be used for manned high-speed runs of up to 500 kilometres an hour and to test the Maglev on inclines and curves and in tunnels. So far the Maglev has been tested only on the straight $7-\mathrm{km}$ track in Kyushu. But before it goes into commercial operation, the Railway Technical Research Institute which developed the train will have to find a way of shielding passengers from the strong magnetic field of the trains superconducting magnets. Watches, computers and heart-pacemakers are liable to stop when inside the institute's present test train (MU 002).

Apart from these technological hurdles, there are strong forces resisting plans of Maglev proponents to extend the line to Osaka and Tokyo. An Osaka-Tokyo Maglev could whisk passengers between the two cities in an hour instead of three hours by conventional bullet train. But this would threaten the commercial base of the existing bullet train lines (Shinkansen).

When JNR was privatized, the company had an accumulated debt of more than $¥ 25$ million million ( $\$ 185,000$ million), much of it resulting from the building of Shinkansen. The debt, which was passed to a semi-governmental company (the Japanese National Railways Settlementof-account Enterprise) separate from the JR railway companies, has since risen to $¥ 27$ million million, and interest payments on the debt alone amount to about 